\title{
COMPARITIVE STUDY OF ENDO-NASAL ENDOSPIC DACRYOCYSTORHINOSTOMY WITH OR WITHOUT INTRAOPERATIVE MITOMYCIN C
}

Sanjeev Rohatgi ${ }^{1}$, Sandeep Kaushik².

1. Associate Professor, Department of Ophthalmology, Government Medical College, Kanauj.

2. Associate Professor, Department of ENT, Government Medical College, Kanauj.

\section{CORRESPONDING AUTHOR:}

Dr. Sanjeev Rohatgi,

10/503-B Allenganj, Tilak Nagar,

Kanpur (UP).

E-mail: snjvrohatgi@yahoo.co.in

\begin{abstract}
The present study was undertaken with a view to identify the role of the anti-fibroblastic activity of Mitomycin C IN preventing scarring at the osteotomy site in endoscopic dacryocystorhinostomy.

A common cause of failure in DCR surgery is the closure of the osteotomy with soft tissue obstruction at the common canaliculus. If an antiproliferative agent such as MMC and 5-florouracil are applied at this area, it may reduce fibrosis to give a better result.

For this study, patients coming to our OPD with complaints of chronic dacryocystitis, epiphora, and discharge from eye due to nasolacrimal duct blockage were selected. They underwent endoscopic DCR. For this randomized study, the patients were divided into 2 groups;
\end{abstract}

- The control group

- Those who underwent surgery with local application of MMC

Patients underwent post -operative examination for complications like haemorrhage, wound infections, crusting, synechia \& granulations. It was observed that the control group (without application of MMC) had more complications than the MMC group.

The periods of observations were 1 week, 3 weeks and 3 months respectively. The patency of the duct was found to be more in MMC group than in control group. Duct patency was judged by clear flow of saline into the nasal cavity on syringing.

Thus, it was concluded that, the adjunctive use of a wound healing inhibitor is considered to increased success rate of endoscopic, endonasal DCR.

INTRODUCTION: The endoscopic approach has several advantages; it provides aesthetic result with no external scar. It allows a one-stage procedure to also correct associated nasal pathology that may be causative. It avoids injury to the medical canthus and/or pathologic scar formation. It preserves the pumping mechanism of the orbicularis oculi muscle. The first report of dacryocystorhinostomy was by CALDWELLIN 1893 .Caldwell created a rhinostomy using a intranasal approach by removing a portion of the inferior turbinate $\&$ following the nasolacrimal duct to the lacrimal sac and described the operation via the endonasal approach. In 1980 McDonough and Meiring Used the modern nasal endoscopic approach and described improved results. 
The two most common causes of failure in DCR surgery are closure of the surgically created osteotomy with the soft tissue obstruction at the common canaliculus. Antiproliferative agent applied at the osteotomy site may reduce the fibrosis and hence the failure rate. Mitomycin $\mathrm{C}$ and 5fluorourical have been equally successful in this regard .

In this prospective randomized study, we aim to identify role of mitomycin $\mathrm{C}$ in endosal endoscopic dacryocystorhinostomy and to correlate the efficacy of endosal endoscopic dacryocystorhinostomy with or without mitomycin C.

MATERIALS AND METHOD: For the present study 60 cases of chronic dacryocystitis were selected and underwent endoscopic DCR at our institution from December 2010-August 2012. Patients presenting with epiphora and discharge from eye due to a distal obstruction of nasolacrimal duct were included in the criteria for endoscopic DCR.

Patient included into the study were divided into 2 groups, the control undergo endosal dacryocystorhinostomy with local application of mitomycin C (MMC).

Patients of proximal duct obstruction, revision cases and patients who did not follow-up for 3 months were excluded from our study.

\section{OPERATIVE PROCEDURE:}

- All procedures were done under LA/GA.

- Patient's head was tilted 15 degree upwards and turned to the right of the patient i.e. towards the surgeon

- A $4 \mathrm{~mm}, 0$ or 30 degree endoscope was introduced into the nasal cavity and whole of the nasal cavity was visualized.

- The mucosa of the lateral nasal wall infiltrated with $2 \mathrm{ml}$ of $2 \%$ Xylocaine with 1:100,000adrenaline just anterior to the uncinate process.

- The $1.5 \times 2 \mathrm{~cm}$ piece of mucosa anterior to the anterior attachment of middle turbinate removed off after incision with sickle knife.

- Corresponding lacrimal bone and frontal process of maxilla removed using kerrison bone punch starting from maxillary line.

- Medial wall of sac is incised using sickle knife and excised as much as possible using blakesley forcep.

- Patency is checked by saline irrigation via inferior canaliculus and flow into nasal cavity through new stoma is visualized.

- Light anterior nasal packing for hemostasis

- Intra operative use of mitomycin C

- A piece of merocel surgical sponge soaked in $0.2 \mathrm{mg} / \mathrm{ml}$ mitomycin $\mathrm{C}$ was applied over osteotomy margins for 5 minutes.

\section{POST-OPERATIVE CARE}

- The nasal pack was removed after $24 \mathrm{hrs}$.

- All patients were given systemic oral antibiotic and analgesics for 5 days. Antibiotic eye drops were advised 6 times daily for 3 days .Nasal decongestant drops were instilled 6 drops 3 times a day for 3 days. 
- All patients were followed at first week, third week and third month post operatively.

- Nasal endoscopy with syringing was done in each visit and looked for patency, and crusting, granulations \& secretions and were removed.

- On the bases of these findings results were classified into patent, partially blocked and completely blocked nasolacrimal ducted and compared with each group of evaluate the success rate.

\section{OBSERVATIONS}

Table 1: SYMPTOMATOLOGICAL DISTRIBUTION

\begin{tabular}{|l|l|l|l|}
\hline SYMPTOMS & $\begin{array}{l}\text { CONTROL GROUP } \\
\text { WITHOUT MMC } \\
\text { NO. }\end{array}$ & $\begin{array}{l}\text { MMC GROUP } \\
\text { NO. }\end{array}$ & $\begin{array}{l}\text { TOTAL } \\
\text { NO. }\end{array}$ \\
\hline $\begin{array}{l}\text { Simple Epiphora without } \\
\text { discharge }\end{array}$ & 3 & 2 & 5 \\
\hline $\begin{array}{l}\text { Epiphora associated with } \\
\text { Discharge }\end{array}$ & 27 & 28 & 55 \\
\hline
\end{tabular}

TABLE 2: CLINICAL CHARACTERISTIC OF CASES

\begin{tabular}{|l|l|l|}
\hline & Control group without MMC & MMC GROUP \\
\hline Number of cases & 30 & 30 \\
\hline Mean age & 33.43 & 33.36 \\
\hline Sex ratio & $1: 3.28$ & $1: 3.28$ \\
\hline
\end{tabular}

TABLE 3: COMPLICATIONS

\begin{tabular}{|l|l|l|l|l|}
\hline \multirow{2}{*}{} & \multicolumn{3}{|l|}{ Control group without MMC } & \multicolumn{2}{l|}{ MMC GROUP } \\
\cline { 2 - 5 } & NO. & $\%$ & NO. & $\%$ \\
\hline Haemorrhage(primary) & 1 & 3.33 & 1 & 3.33 \\
\hline Wound infection & 2 & 6.67 & 1 & 3.33 \\
\hline Crusting & 10 & 33.33 & 8 & 26.67 \\
\hline Synechiae & 3 & 10 & 1 & 3.33 \\
\hline Granulations & 4 & 13.33 & 3 & 10 \\
\hline
\end{tabular}

\begin{tabular}{|c|c|c|c|c|c|c|}
\hline \multirow{2}{*}{$\begin{array}{ll}\text { Period } & \text { of } \\
\text { observation }\end{array}$} & \multicolumn{3}{|c|}{ Control group Without MMC } & \multicolumn{3}{|c|}{ MMC group } \\
\hline & Patent $\%$ & $\begin{array}{l}\text { Partially } \\
\text { blocked (\%) }\end{array}$ & $\begin{array}{l}\text { Blocked } \\
(\%)\end{array}$ & Patent $\%$ & $\begin{array}{l}\text { Partially } \\
\text { blocked (\%) }\end{array}$ & Blocked (\%) \\
\hline $1^{\text {st }}$ week & 90 & 6.67 & 3.33 & 96.67 & 3.3 & 0 \\
\hline $\mathrm{d}^{\mathrm{d}}$ week & 86.67 & 6.67 & 6.67 & 93.33 & 3.33 & 3.33 \\
\hline $3^{\text {rd }}$ month & 83.33 & 3.33 & 13.33 & 90 & 3.33 & 6.67 \\
\hline
\end{tabular}




\section{ORIGINAL ARTICLE}

RESULTS: All the sixty patients (100\%) had epiphora as the main complaint .Of these, 55 patients had purulent discharge associated with epiphora (table: 1). In our study patients were divided with equal sex ratio (1:3.28) with 7 males and 23 females in each group. Mean age of control group was 33.33 and that of MMC group was 33.36.

All patients underwent endoscopic DCR and as shown in Table: 3 both groups had intraoperative hemorrhage in 3.33\% patients but hemostasis was achieved at the end of the procedure. Two patients of the controlled group suffered from wound infection (6.67\%) and one patient from the MMC group had similar complaints, which were successfully treated with antibiotics. Ten patients (33.3\%) of the control group and 8 patients of the MMC group had post-operative excessive crusting, which were removed at each follow-up. Three (10\%) patients of the control group and 1 patient $(3.33 \%)$ of the MMC group had granulations postoperatively, which were seen at regular follow-up. Four $(13.33 \%)$ patients of the control group and 3 (10\% patients of MMC group had synechiae in the nasal cavity (Table-3).

In our study, patients were followed-up on $1^{\text {st }}$ week, $3^{\text {rd }}$ week and 3 months. $83.33 \%$ of the patients in control group and $90 \%$ of those in MMC group showed complete cure with clear flow of saline into nasal cavity on sac syringing.

DISCUSSION: In the present study, success rate of $83.33 \%$ in endoscopic dacryocystorhinostomy without MMC (control group) and 90\% in endoscopic dacryocystorhinostomy with intraoperative mitomycin-C (MMC group) was achieved. No significant difference exists between two groups.

Zilelioglu et al (1998) found that success rate of endoscopic dacryocystorhinostomy with intraoperative MMC was $77.3 \%$, whereas without MMC was $77.8 \%$ for ostium size. Hence, there was no difference between two groups regarding ostium size and success rate.

Roozitalab et al (2004) suggested that use of intraoperative MMC in dacryocystorhinostomy does not change success rate of this procedure.

Farahani et al (2008) conducted prospective double-blind randomized clinical trial and showed that patients with nasolacrimal duct obstruction, who underwent endoscopic dacryocystorhinostomy did not benefit from adjunctive topical application of MMC.

Although clinically, there were lesser complications in MMC group as compared to control group, but statistically, they were not significant; however, the results were comparable to the above studies.

CONCLUSION: Utilizing the ant fibroblastic activity of MMC in preventing scarring at osteotomy site in endoscopic dacryocystorhinostomy can go a long way in preventing re-blockage and maintaining post-operative patency of passages.

Distinctly, minimum success rate has been achieved in patients undergoing DCR with intraoperative MMC as compared to patients undergoing control DCR.

Adjunctive use of a wound healing inhibitor is considered to increase the success rate of endoscopic endonasal DCR. Its intraoperative use seems to be easy and safe. But the study of this

limited series shows no benefit in using it and warrants further evaluation in larger numbers having survival studies in future.

\section{REFERENCES:}




\section{ORIGINAL ARTICLE}

1. Valentine Fernades S. Dacryocystorhinostomy [internet] 2010[updated Apr 26, 2010] available from: http//emedicine.medscape.com/article/879096-overview.

2. Caldwell GW. Two new operations for obstruction of the nasal duct with preservation of the canaliculi \& an incidental description of a new lacrimal probe. New York Medical Journal 1893, 57-581-2.

3. McDonough M, Meiring JH endoscopic transnasal dacryocystorhinostomy. J Laryngol Otol 1989, 103:585-587.

4. Neil Fergie, Nicholus S Jones Dacryocystorhinostomy In : Micheal Gleeson, editor ScottBrown's Otorhinolaryngology head and neck surgery $7^{\text {th }}$ ed Great Britain Hodder Arnold; 2008 pp.1689-95

5. Zilelioglu G Ugurbas SH, Anadolu Y, Akiner M, Akurk T. Adjunctive use of MMC on endoscopic lacrimal surgery. Br J opthalmol, 1998 Jan 82 :63-6.

6. Roozitalab MH Amira Hamdi M, Namazi MR Results of the application of intraoperative MMC in Dacryocystorhinostomy .Eur J Opthalmol 2004 Nov-Dec 14(6):461-3.

7. Farahani F Ramezani A Effect of intraoperative mitomycin $C$ application on recurrence of endoscopic Dacryocystorhinostomy. Saudi Med J 2008 Sep 29(9):1354-6. 